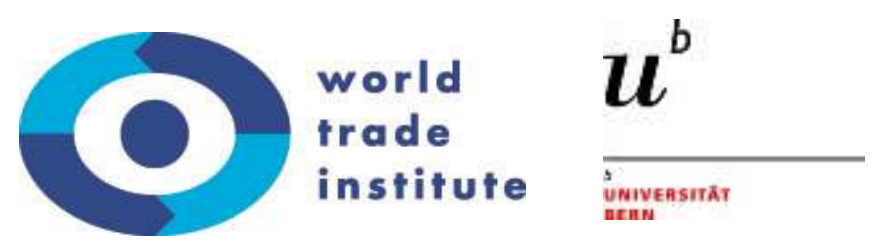

\title{
The TPP and its Relation with Regional and Preferential Agreements in Latin America
}

\author{
Rodrigo Polanco \\ University of Chile \\ rpolanco@derecho.uchile.cl
}

The goal of this paper is to study the impact that the Trans-Pacific Partnership Agreement (TPP) may have on regional and preferential trade agreements (PTAs) in Latin America. If we understand TPP as an ordering project operating both on a mega-regional scale and at a regional dimension, this research examine the influence of TPP wording and commitments on TPP negotiating countries in Latin America (Chile, Mexico and Peru), and on other countries that are not part of the TPP negotiation, including those that share similar features and policy interest with TPP members (Costa Rica, Panama), other that have opposing interest (ALBA countries), or that have kept preferentialism largely on a regional level (MERCOSUR). The paper concludes that TPP has served as fostered convergence for a group of countries in the Latin American region that already had an important participation on preferential trade agreements and investment treaties. It is also likely to influence other countries of the region that have not a large experience on PTAs except under a regional approach (Uruguay and Paraguay). But it is also unlikely that the TPP will influence Latin America countries that are openly against the system of PTAs (Venezuela, Bolivia, and Ecuador) or that have kept themselves outside of the system of PTAs and IIAs (Brazil).

Research for this paper was funded by the Swiss State Secretariat for Economic Affairs under the SECO / WTI Academic Cooperation Project, based at the World Trade Institute of the University of Bern, Switzerland.

SECO working papers are preliminary documents posted on the WTI website (www.wti.org) and widely circulated to stimulate discussion and critical comment. These papers have not been formally edited. Citations should refer to a "SECO / WTI Academic Cooperation Project" paper with appropriate reference made to the author(s). 


\section{THE TPP AND ITS RELATION WITH REGIONAL AND Preferential Agreements In LAtin America}

\section{Regional Economic Integration in Latin America: The Never Ending Story}

The history of Latin American regional economic integration seems to be a never-ending one. Since the independence from their European masters, countries of the region embraced the idea of having an economic integration, besides the even more elusive Bolivarian ideal of having a political union. ${ }^{1}$ Integration efforts have undergone a number of ups and downs, each of them accompanied by fervent enthusiasm, only to backslide with a long list of pledges for deeper integration remaining unfulfilled. While there has been no shortage of dynamism on Latin America's regional scene, real progress in deepening integration has been scarce. Since 1960, Latin American attempts at regionalism have been pursued through different waves, generally associated with specific economic and political models adopted by participating states. They have also tended to diverge across space, gradually giving birth to separate blocs and overlapping projects. ${ }^{2}$ Although the different efforts of regional integration will be presented in principle on a chronological order, some of them do not follow this organizing criterion.

\section{A. Friendship, Commerce and Navigation and Pan-American Integration}

During the $19^{\text {th }}$ century, right after their independence most of Latin American countries signed bilateral treaties of Friendship, Commerce and Navigation (FCN) "to facilitate commerce, navigation, and investment between the States Parties and reciprocally to protect individuals and businesses". 3

Although these treaties were concluded mostly between newly independent States and former colonial masters in order to ensure access of the latter to the expanding markets of the developing world for the sale of finished goods, ${ }^{4}$ securing reciprocal minimum standards of treatment for their

\footnotetext{
${ }^{1}$ Salvador Rivera, Latin American Unification: A History of Political and Economic Integration Efforts (2014).

2 Alberto van Klaveren, 'Regionalism in Latin America' (2016) < http://www.wti.org/institute/news/372/seco-visitingscholar-lectures-on-regionalism-in-latin-america/> accessed 19 September 2016.

3 Andreas Paulus, 'Treaties of Friendship, Commerce, and Navigation' (Max Planck Encyclopedia of Public International Law, March 2011) <http://www.mpepil.com/subscriber_article?script=yes\&id=/epil/entries/law9780199231690-e1482\&recno=1\&searchType=Quick\&query=friendship $>$ accessed 17 October 2016.

${ }^{4}$ One of the most well-known of these agreements was the Treaty of Amity, Commerce and Navigation between Great Britain and the United States or "Jay Treaty" (1794) signed in the aftermath of the American Independence war, which provided for three separate boards of arbitration, including one devoted to resolve British claims of property damage, expropriation and breach of contract affecting British citizens, during the conflict. Christopher F. Dugan and others,
} 
citizens engaging in investment activity in a specific country, a particular characteristic of FCN agreements in Latin America is that they reflected a symmetrical negotiation between former colonies, where the freedoms of commerce and navigation played as key factors to its conclusion as both were heavily limited under the Spanish and Portuguese rule. As an example, Chile signed FCN treaties with Argentina (1826 and 1855), Mexico (1832), Bolivia (1833), Peru (1835 and 1848), including a MFN provision making extensive the benefits of the treaty to other "Hispanic American" republics. ${ }^{5}$

The pursuit of regional economic integration came to the forefront by the end of the 19th century, at the First International Conference of American States (held in Washington, D.C., on October 2, 1889 - April 1890), that created an association entitled the "International Union of American Republics" comprised by the eighteen governments that had participated in the conference, ${ }^{6}$ represented by a bureau known as "the Commercial Bureau of American Republics" who was in charge of the prompt collection and distribution of commercial information of the American Republics, and with the care of all translations and publications as well as the correspondence pertaining to the Union. The Bureau began functioning in late November, 1890, and was renamed the "International Commercial Bureau" at the Second Pan-American Conference (held in Mexico City, on October 22, 1901 - January 31, 1902). ${ }^{7}$ At the Fourth Pan-American Conference (held in Buenos Aires, July 12 - August 30, 1910), the name of the organization was changed to the "Union of American Republics" and the International Commercial Bureau became the "Pan American Union”, and since then took a more political than an economic role. In fact, on 30 April 1948 the Pan-American Union was replaced by the Organization of American States (OAS).

In theory the Bureau was the representative of the eighteen governments that had participated in the conference but practically speaking, right from the outset, the United States acquired direct responsibility for its organization, administration, and operations, and in practice seemed to be in service mostly of the United States of America. For that reason is not strange that the bureau officially reported as achieved tasks the dissemination "among the people of the United States of America" of information respecting "the resources and business opportunities of the Latin American Republics; and, on the other hand, by making known to the people of South and Central

Investor-State Arbitration (Oxford University Press 2008) 35-37.

${ }^{5}$ Universidad de Chile, 'Tratados, Convenios y Acuerdos Internacionales' (Fuentes para el estudio de la Historia de Chile, 2003) <http://www.historia.uchile.cl/CDA/fh_issue2/0,1392,ISID\%253D563\%2526JNID\%253D12,00.html> accessed 14 October 2016.

6 These countries were Haiti, Nicaragua, Peru, Guatemala, Uruguay, Colombia, Argentine, Costa Rica, Paraguay, Brazil, Honduras, Mexico, Bolivia, United States, Venezuela, Chile, Salvador and Ecuador.

7 International Bureau of the American Republics, William Woodville Rockhill and Williams Carlton Fox, International Union of American Republics (Washington [Press of WF Roberts] 1901) 11-12 <http://archive.org/details/internationaluni00inte> accessed 1 November 2016. 
America the many advantages offered to them by the markets of the United States".

\section{B. Closed Regionalism}

It was not until after the Second World War that more concrete effort of economic integration took place at a sub-regional level, as part of a wave that has been labelled as 'closed regionalism' that took place Latin America from the 1950's onwards, and that is characterized by trade agreements that lower or eliminate barriers to trade among member states of a regional organization, which are not extended to third countries. ${ }^{9}$ The intention behind this scheme was promoting regional industries, finding economies of scale and establishing institutions aimed at liberalization between Latin American countries. ${ }^{10}$ As pointed out by Mattli, these commercial unions were triggered by external events, notably after the creation of the European Communities (especially the fear of a protectionist European common market with respect to agricultural policy, and the trade diversion effects derived from the extension of preferential arrangements of individual colonial powers to the whole European community), and deteriorating terms of trade, that impacted in a reduced annual growth rate. ${ }^{11}$

\section{Central American Common Market}

On October 14, 1951 five Central American countries (Costa Rica, El Salvador, Guatemala, Honduras, and Nicaragua), signed the Treaty of San Salvador creating the Organization of Central American States (OCAS, in Spanish "Organización de Estados Centroamericanos" - ODECA) which among other objectives, was created to promote economic, social and cultural development through cooperative and solidary action. ${ }^{12}$ Nine years later, with the signature of the "General Treaty on Central American Economic Integration", at Managua, December 13, 1960 the same countries created the Central American Common Market (CACM), the Central American Bank for Economic Integration and the Secretariat for Central American Economic Integration (SIECA). ${ }^{13}$

\footnotetext{
${ }^{8}$ James F. Vivian, 'The Commercial Bureau of American Republics, 1894-1902: The Advertising Policy, the State Department, and the Governance of the International Union' (1974) 118 Proceedings of the American Philosophical Society 555.

9 Stephen Buzdugan, 'Open and Closed Regionalism' in Mark Bevir (ed), Encyclopedia of Governance (SAGE Publications, Inc 2007) <http://sk.sagepub.com/reference/governance/n365.xml> accessed 1 November 2016.

${ }^{10}$ Alberto van Klaveren (n 2).

${ }^{11}$ Walter Mattli, The Logic of Regional Integration: Europe and Beyond (Cambridge University Press 1999) $140,143$.

12 'Carta de la Organización de Estados Centroamericanos (ODECA)' (October 1951), Art. 1 <http://www.internationaldemocracywatch.org/attachments/230_Carta\%20de\%20la\%20Organizacion\%20de\%20Estad os\%20Centroamericanos\%20(ODECA).pdf> accessed 1 November 2016.

13 'General Treaty on Central American Economic Integration Between Guatemala, El Salvador, Honduras and Nicaragua Signed at Managua, on 13 December 1960' (SICE - Foreign Trade Information System) <http://www.sice.oas.org/trade/camertoc.asp> accessed 1 November 2016.
} 
These regional bodies were complemented with the amendment of the ODECA Treaty in $1962{ }^{14}$ that created new agencies including among others Court of Central American Justice (successor of the Central American Court of Justice - "Corte de Cartago", which operated from 1907 to 1918), ${ }^{15}$ and a Central American Economic Council.

Central American Integration System (CAIS, in Spanish: "Sistema de la Integración Centroamericana" - SICA) is the economic and political organization of Central American states since February 1, 1993. On December 13, 1991, the ODECA countries signed the Protocol of Tegucigalpa, extending earlier cooperation for regional peace, political freedom, democracy and economic development.

CACM was highly successful during its first decade of functioning, with an important reduction of intraregional tariffs that provoked a dramatic increase in intraregional trade (reaching $24.2 \%$ in 1968). But this success story came to end on July 14, 1969, when El Salvadorian army attacked Honduras in what has been known as "the Soccer War", as it was triggered after a World-Cup semi-final match between both countries, but has more complex underlying causes, including the abrupt increase of Salvadorian immigrants in Honduras. ${ }^{16}$ After several thousand dead on both sides, thousands of refugees in the region and the destruction of oil refining and storage facilities, the share of CACM intraregional trade fell to $11,9 \%$ in $1998 .{ }^{17}$ In the $1980-2013$ period CACM exports to the rest of Latin America and the Caribbean had an average annual growth rate of $11.5 \%$, with an average annual rate of variation reported by intra-bloc flows of $6.89 \%$ (of $6.7 \%$ ) to the rest of the world. ${ }^{18}$

\section{Latin America Integration Association}

In February 1960, Argentina, Brazil, Chile, Mexico, Paraguay, Peru, and Uruguay established the Latin America Free Trade Association (LAFTA, in Spanish “Asociación Latinoamericana de Libre Comercio" - ALALC), ${ }^{19}$ established to gradually create a Latin American common market, and to achieve progressively complementarity and integration of their economies, offering tariff rebates

\footnotetext{
14 'Charter of the Organization of Central American States (ODECA) Signed at Panama City, December 12, 1962.' (1963) 2 International Legal Materials 235.

${ }^{15}$ Francisco Orrego Vicuña, International Dispute Settlement in an Evolving Global Society: Constitutionalization, Accessibility, Privatization (Cambridge University Press 2004) 49.

${ }^{16}$ William Durham, Scarcity and Survival in Central America: Ecological Origins of the Soccer War (Stanford University Press 1979).

${ }^{17}$ Walter Mattli (n 11) 145-146.

${ }^{18}$ Latin American and Caribbean Economic System (SELA), 'Assessment Report on Intra-Regional Trade in Latin America and the Caribbean, 1980-2013. XLI Regular Meeting of the Latin American Council. Caracas, Venezuela 25 to 27 November 2015. SP/CL/XLI.O/Di N $\mathrm{N}^{\mathrm{O}}$ 4-15' $58<\mathrm{http}$ //www.sela.org/media/2087742/di-4-comercio-alc-19802013-ing.pdf> accessed 1 November 2016.

19 LAFTA original members were Argentina, Brazil, Chile, Mexico, Paraguay, Peru, and Uruguay. Ecuador and Colombia joined in 1961, Venezuela in 1966 and Bolivia in 1967. Walter Mattli (n 11) 141.
} 
among member countries and excluding third parties. ${ }^{20}$ However, the implementation of LAFTA was an arduous and unfinished process that was finally suspended by the end of the decade, facing increased reduction of intraregional trade, while at the same time extra-regional trade was booming. ${ }^{21}$ By the signature of the second Treaty of Montevideo on August 12, 1980, the LAFTA was transformed into the Latin American Integration Association (LAIA, in Spanish "Asociación Latinoamericana de Integración" - ALADI) pursuing the more ambitious goal of improving the economic and social development of the region through the establishment of a common market (inspired by the success of the European Communities). LAIA became the largest Latin American integration effort with thirteen member countries (Argentina, Bolivia, Brazil, Chile, Colombia, Cuba, Ecuador, Mexico, Panama, Paraguay, Peru, Uruguay and Venezuela), together representing 20 million square kilometers and more than 510 million inhabitants. Although LAIA proven to be a more flexible agreement, only granted tariff preferences to around $10 \%$ of all goods traded, ${ }^{22}$ and its success was only partial as it was affected by the collapse of many Latin American economies during the 1980 debt crisis. ${ }^{23}$

\section{Andean Community}

As a reaction to the shortcomings of LAFTA's implementation, and as a way of increasing its voice in Latin American affairs, ${ }^{24}$ in 1969 Chile, Bolivia, Colombia, Peru and Ecuador created the Andean Common Market (ANCOM or Andean Group, in Spanish "Mercado Común Andino" MCA o Pacto Andino), ${ }^{25}$ an effort to liberalize regional trade in that sub-region, establishing wide common economic policies including a common external tariff, joint industrial planning, and the treatment of foreign capital - a feature that was not included neither in LAFTA nor in LAIA. ${ }^{26}$ In 1973, Venezuela became the sixth member of ANCOM, but the group was soon abandoned by Chile in 1976, which took a unilateral path for the liberalization of investment and trade few years after the military coup of 1973, one-sidedly changed its investment and trade policy, moving from substitution of imports to the promotion of exports, liberalizing the domestic financial system, granting national treatment to foreign investors, and unilaterally adopting a standard reduction of

\footnotetext{
${ }^{20}$ Alberto van Klaveren (n 2).

${ }^{21}$ Walter Mattli (n 11) 142.

${ }^{22}$ ibid.

${ }^{23}$ Karl Kaltenthaler and Frank O. Mora, 'Explaining Latin American Economic Integration: The Case of Mercosur' (2002) 9 Review of International Political Economy 72, 72-73.

${ }^{24}$ Walter Mattli (n 11) 147.

${ }^{25}$ The Andean Group was created by the Cartagena Agreement signed on May 26, 1969. Venezuela later joined the Group in 1973.

${ }^{26}$ William P. Avery, 'The Politics of Crisis and Cooperation in the Andean Group' (1983) 17 The Journal of Developing Areas 155, 155.
} 
tariffs. $^{27}$ This led Chile to a withdrawal from the Andean Group in 1976, as there were conflicting positions on common external tariffs and on the treatment of foreign investment. ${ }^{28}$ Chile then focused on promote exports outside the Latin-American region and in the late 80's the country implemented an export-led growth strategy focused on agriculture, instead exclusively on extractive industries. $^{29}$

The Andean Group continued to exist but was no exempt of problems. On May 28, 1979 tried to expand its scope with the creation of a permanent and supranational court of justice. However, the judicial institution only started functioning on January 2, 1984. Subsequently by the Protocol of Cochabamba (in force since August 25, 1999) it was designated with the official name of the Court of Justice of the Andean Community (CJAC or “Andean Tribunal of Justice"). ${ }^{30}$

The Andean Pact was put to the test one more time when an economic crisis in the early 1980s hit the international market, with particular force in Latin America, pushing many economies to return to autarkic policies. Intra-Andean trade crumbled, the common external tariff and sectoral programs floundered, and member countries repeatedly failed to observe the Agreement. The countries in the Pact shared the same vision of industrialization, and still believed strongly in closed economics rooted in nationalism and government interventionism. ${ }^{31}$

A revival of sorts took place in early 1990s with the rise of neoliberal economics and return to democratic governance on the countries of the sub-region. The Trujillo Protocol of March 10, 1996, ${ }^{32}$ replaced the original Pacto Andino with the Andean Community of Nations (CAN) and

\footnotetext{
${ }^{27}$ Directorate General of International Economic Affairs (DIRECON), Chile 20 Años de Negociaciones Comerciales. (Ministry of Foreign Affairs of Chile 2009) 58-59 <http://www.direcon.gob.cl/wp-content/uploads/2013/09/Chile-20a\%C3\%B1os-de-negociaciones-comerciales.pdf > accessed 12 October 2016.

${ }^{28}$ ANCOM member States had accepted a reduction of Chilean tariffs only up to $60 \%$. Between 1975 and 1979 , Chile eliminated all exchange controls and quantitative restrictions, and reduced import tariffs to a uniform $10 \%$ (from an average in excess of 100\%). Although in 1983-1983 tariffs were temporarily raised up to $35 \%$ (the maximum as a "bound" tariff under GATT) after a severe economic crisis, they were then periodically reduced to $11 \%$ by 1991 . Sebastian Edwards and Daniel Lederman, 'The Political Economy of Unilateral Trade Liberalization: The Case of Chile, NBER Working Paper No. 6510'4-9 <http://www.anderson.ucla.edu/faculty/sebastian.edwards/W6510.pdf> accessed 19 September 2016.

29 Maria Elena Varas, Export Growth and Diversification: A Policy Analysis for the Case of Chile (2012) 3 <http://www.resourcegovernance.org/sites/default/files/RWI_Econ_Diversification_Chile.pdf> accessed 19 September 2016.

${ }^{30}$ Since this reform, the CJAC was endowed with functions on arbitration, opening the possibility of submitting international disputes to the community jurisdiction and allowing access of individuals to the new arbitral jurisdiction. Aníbal Sierralta, 'Los Mecanismos de Solución de Controversias En La Comunidad Andina de Naciones: Desarrollo, Tendencias y los Desafíos Del Comercio Internacional' [2005] CEPAL 26 $<$ http://eclacpos.org/brasil/noticias/paginas/2/22962/SIERRALTA-

MECANISMOS\%20SOLUCI\%C3\%93N\%20CONTROVERSIAS\%20COMUNIDAD.pdf> accessed 17 October 2016.

${ }^{31}$ Robben Dashiell Hixson, 'The Andean Community: A Case Study on Economic Integration' (The University of Utah 2011) 35 <http://content.lib.utah.edu/utils/getfile/collection/etd3/id/829/filename/821.pdf> accessed 1 November 2016.

32 'Comunidad Andina - Protocolo de Trujillo, March 10, 1996' (SICE - Foreign Trade Information System) <http://www.sice.oas.org/trade/junac/carta_ag/Trujillo.asp> accessed 1 November 2016.
} 
created the Andean Integration System, establishing a whole array of institutions modeled after the European Union, including an Andean Commission, with the Andean Presidential Council becoming the highest body. But the CAN faced another important crisis ten years later, as in May 2006 Venezuela left the Community. ${ }^{33}$ During 2005, Venezuela had decided to join another effort of regional integration: the Southern Common Market (MERCOSUR) and a year later, in April 2006, the then Venezuelan President Hugo Chávez announced his country's withdrawal from the CAN, declaring that the Community was "dead", becoming obsolete after Colombia and Peru had signed free trade agreements with the United States. ${ }^{34}$

\section{Caribbean Integration}

There are several efforts of Caribbean integration. The most important one is the Caribbean Community (CARICOM, for its acronym in English) which was established on July 4, 1973, through the signing of the Treaty of Chaguaramas, Trinidad and Tobago, to transform the Caribbean Free Trade Association (CARIFTA) in a Common Market. CARIFTA had been previously organized between 1965-1972 to provide a continued economic linkage between the English-speaking Caribbean countries following the dissolution of the West Indies Federation, which lasted from January 3, 1958 to May 31, 1962. Today 15 countries integrate CARICOM: Antigua and Barbuda, Bahamas, Barbados, Belize, Dominica, Granada, Guyana, Haiti, Jamaica, Montserrat, Saint Kitts and Nevis, Saint Lucia, Saint Vincent and the Grenadines, Suriname and Trinidad and Tobago.

The declared objectives of CARICOM are to raise the standard of living and work of nations in the region, end unemployment, accelerate, coordinate and sustain economic development. Also, to promote trade and economic relations with third countries and groups of nations. ${ }^{35}$

To fulfill these goals, an integrated development strategy was envisioned at the $10^{\text {th }}$ Meeting of the Conference of Heads of Government of CARICOM which took place in July 1990 in Grand Anse, Grenada. The Caribbean Single Market and Economy (CSME), aims to deepening economic integration between CARICOM members by advancing beyond a common market towards a single market and economy, and the progressive insertion of the region into the global trading and economic system by strengthening trading links with non-traditional partners.

The CSME should have been started in January 2006, but has been subsequently delayed and is not

\footnotetext{
${ }^{33}$ Ludger Kühnhardt, Region-Building: Vol. II: Regional Integration in the World: Documents (Berghahn Books 2010) 123.

${ }^{34}$ From Bloomberg News, 'Venezuela to Withdraw From Free Trade Pact' Los Angeles Times (20 April 2006) <http://articles.latimes.com/2006/apr/20/business/fi-briefs20.8> accessed 1 November 2016.

35 'Treaty Establishing the Caribbean Community. Chaguaramas, 4th July 1973' (SICE - Foreign Trade Information System, 1973) <http://www.sice.oas.org/Trade/CCME/Chaguaramastreaty_e.pdf> accessed 28 October 2016.
} 
yet fully implemented.

CARICOM partially overlaps with the Association of Caribbean States (ACS, in Spanish, “Asociación de Estados del Caribe" - AEC) formed on July 24, 1994 by a Convention signed in Cartagena de Indias, Colombia, with the aim of promoting consultation, cooperation, and concerted action among all the countries of the Caribbean. The primary purpose of the ACS is to develop greater trade between the nations, enhance transportation, develop sustainable tourism, and facilitate greater and more effective responses to local natural disasters. ${ }^{36}$ The secretariat of the organization is located in Port of Spain, Trinidad and Tobago. ${ }^{37}$

The ACS has held only seven summits involving Heads of State or Government after more than 20 years of being created, and for some it has failed to establish a record worthy enough for its evaluation as a developmental coalition. ${ }^{38}$

CARICOM also partially overlaps with the Organization of Eastern Caribbean States (OECS) a group on ten small countries with open economies highly prone to natural disasters, having full Member States (Antigua and Barbuda, Commonwealth of Dominica, Grenada, Montserrat, St Kitts and Nevis, Saint Lucia and St Vincent and the Grenadines), with the British Virgin Islands, Anguilla and Martinique as associate members. The OECS was created by the Treaty of Basseterre (capital of St. Kitts and Nevis) on 18 June 1981, being the successor of the Leewards Islands' political organization known as the West Indies Associated States (WISA). The 1981 Treaty was replaced in 2010 with a Revised Treaty of Basseterre, creating an economic union. The Revised Treaty establishes a single financial and economic space within which goods, people and capital move freely, monetary and fiscal policies are harmonized and countries continue to adopt a common approach to trade, health, education and the environment, as well as to the development of such critical sectors as agriculture, tourism and energy. ${ }^{39}$

The most successful achievement of the OECS to date has been to establish a stable and functioning monetary union. All the sovereign members of the OECS plus at least two British

\footnotetext{
36 'Convention Establishing the Association of Caribbean States (ACS), Cartagena de Indias, 24 July 1994' $<$ http://www.acs-aec.org/index.php?q=documents/legal/1994/convention-establishing-the-association-of-caribbeanstates-acs> accessed 1 November 2016.

${ }^{37}$ ACS comprises twenty-five member states (Antigua and Barbuda, Bahamas, Barbados, Belize, Colombia, Costa Rica, Cuba, Dominica, Dominican Republic, El Salvador, Grenada, Guatemala, Guyana, Haiti, Honduras, Jamaica, Mexico, Nicaragua, Panama, St. Kitts and Nevis, St. Lucia, St. Vincent and the Grenadines, Suriname, Trinidad and Tobago, and Venezuela) and seven associate members: Aruba, Curaçao, France (on behalf of: French Guiana, Saint Barthélemy), Guadeloupe, Martinique, Netherlands (on behalf of: Bonaire, Saba, and Sint Eustatius), Saint Martin, Sint Maarten, and Turks and Caicos Islands.

38 H. Michael Erisman, 'International Relations' in Richard S. Hillman and Thomas J. D'Agostino (eds), Understanding the Contemporary Caribbean (Lynne Rienner Pub 2003) 169.

39 'Revised Treaty of Basseterre Establishing the Organisation of Eastern Caribbean States Economic Union. St. Lucia, June 18, 2010' <http://www.oecs.org/index.php/lsu-resources/revised-treaty-of-basseterre> accessed 2 November 2016.
} 
colonies (Anguilla and Montserrat) have one Central Bank that is headquartered in St. Kitts and they all share the same monetary unit (the Eastern Caribbean dollar). ${ }^{40}$ However, the full implementation of the other elements of the economic union is still pending.

The impact of the 2008 global financial crisis was severe in OECS countries as tourism, remittances, and financial activity decreased sharply, growth rates plummeted, debt and fiscal imbalances increased to high levels, and labor market conditions deteriorated. Despite high human development indices, OECS countries have not succeeded in reducing poverty to levels compatible with their level of per capita income. Unemployment, especially among women and youth, remains high. $^{41}$

\section{Open Regionalism}

A second wave of regional integration saw the evolution of "open regionalism", which promoted global trade liberalization across Latin America. If the closed regionalism was a response to the post-Second World War era challenges, the open regionalism could be considered as the answer to the demands of growing and manifest dynamics of economic globalization which began in the mid1980s and sharply increased after the end of the Cold War. ${ }^{42}$ The concept of open regionalism was introduced at APEC (Asia Pacific Economic Cooperation) meetings in the mid-1990's, without a uniformly agreed definition. It has been defined as the "external liberalization by trade blocs, that is, the reduction in barriers on imports from non-member countries that is undertaken when member countries liberalize the trade among themselves. The degree of liberalization on imports from non-members need not be as high as that for member countries". ${ }^{43}$ Open regionalism, is more outward oriented to where intraregional trade preferences are extended to countries outside the region in a movement toward greater trade liberalization. The open regionalism is associated with the liberal policies of the "Washington Consensus", as it was based on regional trade agreements with low external tariffs and trade barriers and wider intra-group liberalization, in order to give

\footnotetext{
${ }^{40}$ Thomas Andrew O'Keefe, 'The Role the Organization of Eastern Caribbean States (OECS) Plays within the Caribbean Common Market and Community (CARICOM) and in the Caribbean's Relationship with the World Economy' (1 February 2010) 7 <http://mercosurconsulting.net/images/20100219OECS_CARICOM.pdf> accessed 1 November 2016.

41 World Bank, 'Organization of Eastern Caribbean States Overview' (16 September 2016) <http://www.worldbank.org/en/country/oecs/overview> accessed 2 November 2016.

${ }^{42}$ José Antonio Sanahuja, 'Regionalismo Post-Liberal Y Multilateralismo En Sudamérica: El Caso de UNASUR' in Andrés Serbin, Laneydi Martínez and Haroldo Ramanzini Junior (eds), El regionalismo 'post-liberal' en América Latina y el Caribe: Nuevos actores, nuevos temas, nuevos desafios, vol 9 (2012) $25<$ http://www.ieeiunesp.com.br/portal/wp-content/uploads/2012/10/2012-Anuario-CRIES-1.pdf> accessed 1 November 2016.

${ }^{43}$ Shang-Jin Wei and Jeffrey A. Frankel, 'Open Regionalism in a World of Continental Trade Blocs' [1998] Staff Papers Vol 45 No 3 (September 1998) 440, 441.
} 
markets a greater role in promoting efficiency and international competitiveness. ${ }^{44}$

This new wave of regionalism was also triggered by external factors, notably the enlargement and deepening of the European Union after the end of the Cold War - with Latin America fearing that would be relegated to a second place after Eastern Europe, which could affect their trade, investment and aid. ${ }^{45}$ The idea of further economic integrate the Americas became suddenly appealing again in opposition to the "other" union.

\section{NAFTA}

The Enterprise for the Americas Initiative (EAI) was launched by the United States in 1990, in order to expand investment in Latin America and the Caribbean and provide some debt relief to countries in the region. The three components of the EAI were: the development of free-trade agreements (FTAs), and a program of official debt relief, and a US\$1.5 billion grant fund to support the implementation of investment reform programs in Latin American countries. ${ }^{46}$

But another catalyst of the open regionalism in Latin America was an internal one, and a direct consequence of the EAI: the "defection" of Mexico with the signature in December 1992 of the North American Free Trade Agreement (NAFTA, in Spanish "Tratado de Libre Comercio de América del Norte" - TLCAN), in force since January $1^{\text {st }}$, 1994, which was seen for some countries of the region as a weakening of the traditional resistance of Latin American countries to US hegemony. But the EAI promised to expand NAFTA if the other governments in the region opened their economies and liberalized their trade and investment, but also incorporating environmental and social issues in the agenda, following Mexico example. ${ }^{47}$

A landmark point on this wave was the failed negotiation of the agreement on a Free Trade Area of the Americas (FTAA, in Spanish Área de Libre Comercio de las Américas - ALCA), stretching from Alaska to Tierra del Fuego in 1994. Serious negotiations took place but the movement to link all the economies of the America was interrupted by the end of the decade. The project met increasing opposition in Latin America, to be finally abandoned in 2005, due to political changes in the region that favored a 'post-liberal' regionalism, led by countries like Venezuela, Argentina, and Ecuador. What survived was a series of free-trade agreements between specific Latin American countries and the United States. ${ }^{48}$

But some countries insisted in be part of the NAFTA model. In December 1994, Chile was invited

${ }^{44}$ José Antonio Sanahuja (n 42) 25.

${ }^{45}$ Walter Mattli (n 11) 152.

46 'Enterprise for the Americas Initiative' (USAID, 28 February 2014)

<https://www.usaid.gov/biodiversity/TFCA/enterprise-for-the-americas-initiative> accessed 1 November 2016.

${ }^{47}$ Robert A. Pastor, 'The North American Free Trade Agreement: Hemispheric and Geopolitical Implications' (1994)

36 The International Executive 3.

${ }^{48}$ Alberto van Klaveren (n 2). 
to start negotiations to join the (NAFTA), ${ }^{49}$ a process that did not succeed as the Clinton Administration was unable to obtain a special mandate to negotiate on behalf of the United States Congress ("fast track"). ${ }^{50}$ This led Chile to adopt a new strategy: negotiating separate FTAs with each NAFTA member. ${ }^{51}$ Thus, in December 1996, Chile entered into an FTA with Canada and in 1998 with Mexico. After lengthy negotiations, Chile finally signed an FTA with the United States in June 2003, which entered into force on January 1, 2004. Colombia would soon follow the Chilean example, signing an FTA with Mexico in 1994, with the United States in 2006, and with Canada in 2008. Peru also followed a similar path, concluding an FTA with the United States in 2006, with Canada in 2008 and finally with Mexico in 2008.

\section{MERCOSUR}

But not all Latin American countries were eager to be economically integrated under US leadership. MERCOSUR was created when Argentina, Brazil, Paraguay, and Uruguay signed the Treaty of Asunción on March 26, 1991 to promote the "free movement of goods, services and factors of production between countries through, inter alia, the elimination of customs duties and non-tariff restrictions on the movement of goods, and any other equivalent measures".

MERCOSUR countries agreed to eliminate customs duties, implement a common external tariff (CET) of $35 \%$ on certain imports from outside the bloc, adopt a common trade policy toward third countries, and allow MERCOSUR residents to live and work anywhere within the bloc. ${ }^{52}$

MERCOSUR quickly went beyond trade policy, and created political institutions aimed to go deeper than most FTAs. By the Protocol of Ouro Preto (signed two years after the signature of NAFTA, on December 17, 1994), several internal agencies were established: the Common Market Council (which congregates the minister of foreign affairs and economy of the members) as the highest decision-making body; the Common Market Group (CMG), to be in charge of coordinating macroeconomic policies among members; and the MERCOSUR Trade Commission (MTC), a body responsible for assisting the $\mathrm{CMG}$, to monitor the application of the common trade policy instruments agreed by the States Parties in connection with the operation of the customs union.

\footnotetext{
${ }^{49}$ NAFTA is a free trade agreement between Canada, Mexico and the United States, that was signed in San Antonio, Texas on December 17, 1992, and came into force on January 1, 1994.

${ }^{50}$ Felipe Larraín, 'América Latina a Las Puertas Del Siglo XXI: Hacia Una Asociación Transpacífica' in Pilar Alamos, Luz O'Shea and Manfred Wilhelmy (eds), América Latina y Asia-Pacífico : oportunidades ante la crisis (1st edn, Instituto de Estudios Internacionales, Universidad de Chile 1998) 379 <http://www.libros.uchile.cl/files/presses/1/monographs/284/submission/proof/index.html\#9> accessed 19 September 2016.

${ }^{51}$ Directorate General of International Economic Affairs (DIRECON), Chile 20 Años de Negociaciones Comerciales. (n 27) 66.

52 Danielle Renwick, 'Mercosur: South America's Fractious Trade Bloc' (Council on Foreign Relations, 5 October 2016) <http://www.cfr.org/trade/mercosur-south-americas-fractious-trade-bloc/p12762> accessed 1 November 2016.
} 
Other important organs created by this Protocol were the MERCOSUR Administrative Secretariat (MAS) and the Structural Convergence Fund (FOCEM), which coordinates regional infrastructure projects. ${ }^{53}$ MERCOUR Parliament, known as PARLASUR was established by a Constitutive Protocol signed on December 9, 2005, but only started functions on 7 May 2007.

The initial outcome of MERCOSUR was rather positive: the trade within the bloc grew from $\$ 4$ billion in 1990 to $\$ 20$ billion in 1997, and in its first decade MERCOSUR concluded trade agreements with Bolivia, Chile, Israel, and Peru. ${ }^{54}$

But soon some problems arose. Regional integration slowed following Brazil's currency devaluation, in 1999, and Argentina's financial crisis, in 2001. Although Argentina and Brazil undertook significant reductions to their bilateral and applied MFN tariffs alongside the implementation of the MERCOSUR, the average MFN tariff that each country applied toward imports from the rest of the world has been mostly unchanged since the mid-1990s. ${ }^{55}$ Both countries have continuously failed to coordinate changes in important trade and investment policies applied toward non-members such as China, to whom Brazil has unilaterally imposed antidumping restrictions on steel imports. For numerous products Argentina and Brazil also frequently do not engage in bilateral free trade, and for others, they applying antidumping measures against each another. ${ }^{56}$ As a consequence, trade disputes have proliferated between Argentina and Brazil. For example, in 2011 Argentina canceled automatic licensing for hundreds of imports, causing delays at ports and contributing to a $15 \%$ decline in Brazilian exports in $2012 .{ }^{57}$ Politically negotiated exceptions to the bloc's rules have become the norm.

With respect to agreements with third countries, MERCOSUR seemed to have privileged a limited amount of negotiations and mostly in a South-South context. These negotiations include six countries, four of them members of the Latin American Integration Association - LAIA (Bolivia, Chile, Mexico and Peru) and two external to this agreement (Egypt and Israel), and the Southern African Customs Union (SACU), which includes Botswana, Lesotho, Namibia, South Africa and Swaziland. In 1999, MERCOSUR started trade negotiations with the European Union - a process that is still ongoing, without any concrete results yet. On December 8, 2004 MERCOSUR and the CAN signed a reciprocal associate-member status agreement and issued the Cusco Declaration

\footnotetext{
53 'Additional Protocol to the Treaty of Asunción on the Institutional Structure of MERCOSUR. Protocol of Ouro Preto, December 17, 1994.' <http://www.sice.oas.org/trade/mrcsr/ourop/ourop_e.asp> accessed 1 November 2016.

${ }^{54}$ Danielle Renwick (n 52).

${ }^{55}$ Chad Bown and Patricia Tovar, 'MERCOSUR Is Not Really a Free Trade Agreement, Let Alone a Customs Union' <http://voxeu.org/article/mercosur-not-really-free-trade-agreement-let-alone-customs-union> accessed 19 September 2016.

${ }^{56}$ Christian Arnold and Berthold Rittberger, 'The Legalization of Dispute Resolution in Mercosur' (2013) 5 Journal of Politics in Latin America 97.

${ }^{57}$ Danielle Renwick (n 52).
} 
stating that they would create a political South American Community of Nations, invoking "Bolivar's dream". 58

Further political and economic problems have complicated MERCOSUR plans. The 1998 Ushuaia Protocol on Democratic Commitment, stating that a rupture in democratic order would be cause for a member's suspension was invoked for the first time in 2012 to suspend Paraguay after the impeachment of then President Fernando Lugo. Although Paraguay was readmitted in 2013, in the meantime Venezuela got the approval of the remaining members to become the fifth member of the bloc in 2012. But by 2016, after years of economic mismanagement, political instability and low oil prices, Venezuela's economy is in a huge economic crisis, that has not benefitted MERCOSUR outlook. In September 2016, the other MERCOSUR members issued an ultimatum: Caracas would have until December 1 to meet its membership requirements by incorporating a joint economic agreement and committing to protecting human rights, or else be suspended. ${ }^{59}$

\section{Bilateral Preferential Trade Agreements}

But outside NAFTA and MERCOSUR, open regionalism was pursued bilaterally, mostly with trading partners outside the Latin American region. Some countries were particularly active in this regard, like Chile, Mexico, Peru, Costa Rica, Panamá and Colombia.

The conclusion of these PTAs can be seen as a way for smaller economies of the region to escape from the "regional trap" the existing schemes of closed regionalism.

The first step was taken at a regional level. Under the LAIA framework most of these countries negotiated "Economic Complementation Agreements" (ECAs), ${ }^{60}$ with Latin American countries which allowed most of the goods with countries of the region to be traded without tariffs. ${ }^{61}$ Chile signed the first ECA with Argentina in 1991, followed by similar agreements with Mexico in 1991; Colombia, Venezuela and Bolivia in 1993; Ecuador in 1994; Peru in 1998; and Cuba in 1999. ${ }^{62}$

In the 1980s, Mexico had already signed PTAs with Ecuador (1983) and Panama (1985), but only insisted in this scheme after NAFTA, concluding other PTAs with Paraguay in 1994, followed by

\footnotetext{
${ }^{58}$ María Carnevalli, 'Brazil in BRICs, a Manifest Destiny? Opposing Views of Caracas and Itamaraty' in Kornegay, Francis A and Bohler-Muller Narnia (eds), Laying the BRICS of a New Global Order: From Yekaterinburg 2009 to eThekwini 2013 (Africa Institute of South Africa 2013) 324.

${ }^{59}$ Danielle Renwick (n 52).

${ }^{60}$ ECA is a denomination used by Latin American countries in bilateral agreements among themselves to mutually open their markets for goods, which fall within the legal framework of LAIA (Treaty of Montevideo, Art. 11). They point to a greater market opening than Partial Scope Agreements (PSAs, which include tariff reduction but only for a certain group of products), but less than in FTAs. ECAs include all products traded between both countries. Directorate General of International Economic Affairs (DIRECON), 'DIRECON » Glosario' <http://www.direcon.gob.cl/glosario/> accessed 19 September 2016.

${ }^{61}$ Directorate General of International Economic Affairs (DIRECON), Chile 20 Años de Negociaciones Comerciales. (n 27) 70 .

62 ibid 75-84, 91-96, 118-123. The ECA N 32 with Ecuador entered into force on January 1, 1995 and in 2008 it was replaced by the ECA $\mathrm{N}^{\circ} 65$ which entered into force on January 25, 2010.
} 
an ECA with Chile in 1998, with MERCOSUR and Brazil (2002), Bolivia (2010), Peru (2011), and Argentina (2006). Similarly, Colombia had also concluded PTAs in the 1980s, notably with Nicaragua and Costa Rica in 1984. After NAFTA, Colombia restarted the negotiation of these agreements, signing treaties with Panama (1993), CARICOM (1994), Ecuador and Venezuela (2004) and Venezuela (2001).

By mid-90s after NAFTA entered into force, these countries started investment and trade negotiations with non-LAIA members outside the Latin American region, aiming to reconcile regional integration with globalization. This strategy - also been labeled as "additive regionalism" - is defined as sequentially negotiating bilateral Free Trade Agreements (FTAs) with all major trading partners, ${ }^{63}$ enabling the preferential entry of goods and services into those countries. These agreements were more "comprehensive" than the ECAs and generally included broad aspects of the bilateral economic relationship beyond trade in goods, such as cross-border services, intellectual property rights, and further facilitating of access to products on the market, among other matters. ${ }^{64}$ Following the example of NAFTA, investment chapters including Investor-State arbitration started to be included within FTAs concluded by Latin American countries.

Mexico closely followed NAFTA, in the FTAs signed with Colombia and Venezuela (1994) or "G3 Agreement", ${ }^{65}$ Bolivia (1994), Nicaragua (1997), Chile (1998), the Northern Triangle (with El Salvador, Guatemala y Honduras in 2000), and Uruguay (2003). In the last decade, Mexico also followed this pattern in the FTAs with Japan (2004), Peru (2011), Central America (2011), and Panama (2014). Central American countries (Costa Rica, Dominican Republic, El Salvador, Guatemala, Honduras, and Nicaragua) also replicated an updated version of NAFTA in the Central America-Dominican Republic-United States Free Trade Agreement (CAFTA-DR).

Chile continued with its policy of open regionalism focusing mostly in Latin America, Europe and the Asia-Pacific region. In 1999, Chile and several Central American countries agreed on a common set of disciplines with bilateral protocols negotiated then bilaterally with Costa Rica (1999), El Salvador (2000), Honduras (2008), Panama (2008), Guatemala (2010) and Nicaragua (2012). ${ }^{66}$ In 2006, the ECAs with Peru and Colombia were expanded and replaced by separate

\footnotetext{
${ }^{63}$ Glenn W. Harrison, Thomas F. Rutherford and David G. Tarr, 'Chile's Regional Arrangements and the Free Trade Agreement of the Americas: The Importance of Market Access.' in Rómulo A. Chumacero, Klaus Schmidt-Hebbel and Norman Loayza (eds), General Equilibrium Models for the Chilean Economy, vol 9 (1st edn, Central Bank Of Chile 2005) 303.

${ }^{64}$ Directorate General of International Economic Affairs (DIRECON), Chile 20 Años de Negociaciones Comerciales. (n 27) 70 .

${ }^{65}$ Colombia - Mexico - Venezuela, Treaty on Free Trade Between the Republic of Colombia, the Republic of Venezuela and the United Mexican States (1995). Venezuela withdrew from the G3 Agreement in 2006 at the same time it left the CAN.

${ }^{66}$ Organization of American States, 'SICE: Trade Policy Developments: Central America - Chile' (SICE - Foreign
} 
FTAs with both countries that entered into force in 2009.

In 2002, Chile signed an Association Agreement (AA) with the European Union, which was one of the first 'fourth generation' agreements, as is not only incorporates the trade pillar, but also political dialogue and a broad scope of cooperation in a wide range of activities. ${ }^{67}$ The AA refers, among other issues to: the free movement of goods, trade in goods and services, establishment of investment, intellectual property, technical barriers to trade, trade defense, government procurement, cooperation, and dispute settlement. It also includes three additional agreements on sanitary and phytosanitary measures, trade in wine, and the trade in spirits and flavored drinks. ${ }^{68} \mathrm{~A}$ similar agreement was signed in 2003 with non-EU European countries of the European Free Trade Association (EFTA), but solely focused on trade and with only one complementary agreement on trade in agricultural goods. ${ }^{69}$

In the Asia-Pacific Region, Chile concluded PTAs with South Korea (2003), China (2005), Japan (2007), Australia (2008), Malaysia (2010), Vietnam (2011), Hong Kong (2012) and Thailand (2013). ${ }^{70}$ In 2005, Chile concluded a plurilateral agreement in the region: The Trans-Pacific Strategic Economic Partnership Agreement (TPSEP - also known as "P4”) including New Zealand, Singapore and Brunei Darussalam, that would be the direct antecedent of the Trans-Pacific Partnership (TPP).

Peru and Colombia, both members of the Andean Community are caught between two worlds of the closed and open regionalism. Peru started signing a Framework Agreement with Thailand in 2003 and an ECA with MERCOSUR in 2005, but after the conclusion of an FTA with the United States in 2006, expanded its network of agreements following closely that model with Chile (2006), Canada (2008), Singapore (2008), EFTA (2008), China (2009), South Korea (2010), Mexico (2011), Panama (2011), Costa Rica (2011), Japan (2011), Guatemala (2011), the European Union (2012) and Honduras (2015). Recently Peru has concluded a new type of agreement with Brazil the Economic and Trade Expansion Agreement ETEA (2016) that departs from the updated NAFTA model because it does not include investor-state arbitration. Instead, that treaty creates mechanisms to prevent disputes, creating focal points (ombudsmen) to support the investors of the other Party in its territory. In addition, a Joint Committee is established to facilitate the exchange of

Trade Information System) <http://www.sice.oas.org/TPD/CACM_CHL/CACM_CHL_e.ASP> accessed 19 September 2016.

${ }^{67}$ Directorate General of International Economic Affairs (DIRECON), Chile 20 Años de Negociaciones Comerciales. (n 27) 154.

${ }^{68}$ Rodrigo Polanco and Ramon Torrent, Analysis of the Prospects for Updating the Trade Pillar of the European Union-Chile Association Agreement (European Parliament 2016)

<http://bookshop.europa.eu/uri?target=EUB:NOTICE:QA0416462:EN:HTML> accessed 19 September 2016.

${ }^{69}$ European Free Trade Association (EFTA) includes Switzerland, Liechtenstein Norway and Iceland.

${ }^{70}$ A Comprehensive Economic Partnership Agreement (CEPA) is in negotiation with Indonesia since 2013. 
information between the Parties, strengthen mutual investment and create mechanisms for interaction between the private sector and governments.

In the case of Colombia, only a couple of PTAs were signed in the 1980s (with Costa Rica and Nicaragua in 1984), and after a PTA with Panama (1993) and the G-3 Agreement with Venezuela and Mexico (1994) and CARICOM the same year, there were no more bilateral agreements concluded for more than a decade. After an FTA with United States in 2006, Colombia quickly followed the conclusion of similar agreements with Chile (2006), the Northern Triangle (2007), Canada (2008), EFTA (2008), European Union (2012), South Korea (2013) and Costa Rica (2013).

This cycle of open regionalism continued until half of 2000 and marked a relatively consistent period in Latin American regionalism and economic integration.

\section{Post Liberal Regionalism}

The third wave of economic integration in Latin America was that of post-liberal regionalism led by countries that did not favor free trade agreements that took place by mid-2000s. This wave gave rise to new initiatives, including the Alliance for the Peoples of our Americas (ALBA), the Union of South American Nations (UNASUR), and the Community of Latin American and Caribbean States (CELAC). What these initiatives had in common was their aim to exclude trade from regionalism. ${ }^{71}$ Although they started strong with several adherents in the region, ${ }^{72}$ all these schemes have not progressed in recent years, particularly because of the economic crisis that affect to some of their key promoters (notably Venezuela).

\section{ALBA}

The Bolivarian Alternative for Latin America and the Caribbean ("Alianza Bolivariana para los Pueblos de Nuestra América" - ALBA), an organization created by Venezuela and Cuba in December 2004, as an alternative to the neoliberal model of integration, presenting a response to the FTAA (Free Trade Area of the Americas), sponsored by the United States. ${ }^{73}$

In April 2006, after the incorporation of Bolivia as a member, ALBA included a Peoples' Trade Treaty ("Tratado de Comercio de los Pueblos" - TCP) an exchange instrument "intended to benefit the peoples as opposed to the Free Trade Agreements that are geared to increasing the power and

\footnotetext{
${ }^{71}$ Alberto van Klaveren (n 2).

72 Tom Chodor and Anthea McCarthy-Jones, 'Post-Liberal Regionalism in Latin America and the Influence of Hugo Chávez' in Sean W. Burges (ed), Latin America and the Shifting Sands of Globalization (Routledge 2016).

73 The idea of ALBA came out during the Third Summit of the Association of Caribbean States (ACS), held in Margarita Island, Venezuela, on December 11-12, 2001, with the name "Bolivarian Alternative for the Americas". Carlos Moreno, Integración Latinoamericana: ALCA vs. ALBA. Presente y Pasado. Revista de Historia, Universidad de Los Andes. Mérida-Venezuela, Year 12. N²3. Jan-Jun, 2007, pp. 155-178.
} 
the domination of the transnational enterprises". ${ }^{74}$ For that reason, and after the incorporation of Nicaragua (January 2007), Dominica (January 2008), Honduras (August 2008), ${ }^{75}$ Ecuador (June 2009), Saint Vincent and the Grenadines (June 2009), and Antigua and Barbuda (June 2009), the organization changed its name in June 2009 to "Bolivarian Alliance for the Peoples of Our America - Peoples' Trade Treaty" (ALBA-TCP). ${ }^{76}$ Saint Lucia joined ALBA as a full member in July 2013. ${ }^{77}$

The "Bolivarian Alliance" promotes regional integration not only for trade liberalization, but also based on solidarity and complementarity between the countries, with promotion and protection of social rights, particularly. ${ }^{78}$ This was clearly established by the late Venezuelan President Hugo Chavez, one of the founding fathers of ALBA. ${ }^{79}$

In April 2007, during the $5^{\text {th }}$ Presidential Summit of ALBA, Bolivia, Venezuela and Nicaragua, proclaimed their intent to withdraw from the International Monetary Fund, the World Bank ${ }^{80}$ and especially from ICSID, in order to guarantee their sovereign right to regulate foreign investment on their national territories, and expressly rejecting "the diplomatic and media pressure exercised by some multinational companies, which having made vulnerable constitutional rules, national laws, contractual obligations, regulatory environmental and labor resolutions, resist the application of sovereign rules by threatened countries by initiating international arbitration against national states". 81

\section{UNASUR}

UNASUR (Union of South American Nations) was created by a treaty signed in Brasilia on 23 May 2008, at the third Summit of South American Heads of State and is in force since 11 March

\footnotetext{
74 ALBA-TCP, "History of ALBA-TCP", available at http://www.alba-tcp.org/en/contenido/history-alba-tcp (last visited Oct. 13, 2016).

${ }^{75}$ Honduras withdrew from the ALBA on December $15^{\text {th }}, 2009$, after the de facto president Roberto Micheletti issued an executive decree later ratified by the Congress on January $13^{\text {th }}, 2010$, El Tiempo, El Parlamento de Honduras Ratifica Su Salida del ALBA, Jan. 13, 2010, available at: http://www.eltiempo.com/archivo/documento/CMS-6939247 (last visited Oct. 13, 2016).

${ }_{77}^{76}$ ALBA-TCP, op.cit., supra 57.

77 Caribbean Journal, "St Lucia Officially Joins ALBA", August 9, 2013, available at http://www.caribjournal.com/2013/08/09/st-lucia-officially-joins-alba/ (last visited Oct. 13, 2016).

78 Antonios Tzanakopoulos, Denunciation of the ICSID Convention under the General International Law of Treaties, International Investment Law And General International Law: From Clinical Isolation To Systemic Integration, Hofmann, Rainer and Tams, Christian, eds. Nomos, Baden Baden, 2011, available at: SSRN: http://ssrn.com/abstract=1735495 (last visited Oct. 13, 2016).

79 Statement by Hugo Chavez, the President of Venezuela in "What is the ALBA-TCP?", available at: http://www.alternativabolivariana.org/modules.php?name=Content\&pa=showpage\&pid=2080 (last visited Oct. 13, 2016).

${ }^{80}$ Emmanuel Gaillard, The Denunciation of the ICSID Convention, New York Law Journal, Vol. $237 \mathrm{~N}^{\circ} 122$, Tuesday June 26, 2007.

${ }^{81}$ Committee for the Abolition of the Third World Debt, "Bolivia, Venezuela and Nicaragua withdraw together from the ICSID”, May 2, 2007, available at http://cadtm.org/Bolivia-Venezuela-and-Nicaragua (last visited Oct. 13, 2016).
} 
2011. UNASUR members are: Argentina, Brazil, Bolivia, Chile, Colombia, Ecuador, Guyana, Paraguay, Peru, Suriname, Uruguay, and Venezuela.

A majority of UNASUR members are also participants of other initiatives of regional integration. From the twelve member states, five are also members of MERCOSUR, namely Argentina, Brazil, Paraguay, Uruguay, and Venezuela; four are members of the CAN (Bolivia, Colombia, Ecuador, and Peru); three are members of ALBA, namely, Bolivia, Ecuador, and Venezuela; and two South American countries are members of CARICOM (Guyana and Suriname). Chile is an associated state but not formally a member of both MERCOSUR (1996) and CAN (2006). Mexico and Panama are observer states at UNASUR. ${ }^{82}$

The UNASUR objective is to build 'integration and union among its peoples in the cultural, social, economic and political fields, prioritizing political dialogue, social policies, education, energy, infrastructure, financing and the environment, among others, with a view to eliminating socioeconomic inequality, in order to achieve social inclusion and citizen participation, strengthen democracy and reduce asymmetries within the framework of bolstering the sovereignty and independence of the States'. ${ }^{83}$

\section{CELAC}

The Community of Latin American and Caribbean States (CLACS - in Spanish: Comunidad de Estados Latinoamericanos y Caribeños - CELAC) is a regional bloc of Latin American and Caribbean states thought out on February 23, 2010, at the Rio Group-Caribbean Community Unity Summit, and created on December 3, 2011, in Caracas, Venezuela, with the signature of The Declaration of Caracas. CELAC is the successor of the Rio Group and the Latin American and Caribbean Summit on Integration and Development (CALC) ${ }^{84}$

CELAC consists of 33 sovereign countries in the Americas but excluding Canada and the United States, as well as the territories of France, the Netherlands, Denmark and the United Kingdom in the Americas. In that sense, CELAC is clearly an effort to reduce the significant influence of the United States on the politics and economics of Latin America, and is seen as an alternative to the Organization of American States (OAS). ${ }^{85}$

\footnotetext{
${ }^{82}$ UNASUR, <http://www.unasursg.org/>.

83 South American Union of Nations Constitutive Treaty (entered into force 11 March 2011) art 2 (UNASUR Constitutive Treaty).

84 'Presidentes Constituyen La Comunidad de Estados Latinoamericanos Y Caribeños. Granada - Ideal' < http://www.ideal.es/agencias/20100223/mas-actualidad/internacional/presidentes-constituyen-comunidad-estadoslatinoamericanos_201002231745.html> accessed 1 November 2016.

85 'Mexico Gives Birth to the Community of Latinamerican and Caribbean States' (MercoPress) <http://en.mercopress.com/2010/02/24/mexico-gives-birth-to-the-community-of-latinamerican-and-caribbean-states> accessed 1 November 2016.
} 


\section{E. Convergence in Diversity?}

The fourth wave that can be distinguished is taking place now with the coexistence of two different models ('Convergence in Diversity'). These model are the 2012 Pacific Alliance (Mexico, Colombia, Peru and Chile), a trade bloc with deep integration features between like-minded countries which already had a network of bilateral agreements; and the updated Mercosur, another very important trade bloc, including Argentina, Brazil, Uruguay, Paraguay and Venezuela with a different political and economic reality, closer to the post-liberal regionalism. The expectation, is that more bridges will be built between the Latin American countries with new impulses to regionalism. ${ }^{86}$

\section{Pacific Alliance}

The Pacific Alliance (PA) was established in April 2011, and formalized by a Framework Agreement signed in Paranal, Chile on June 6, 2012. ${ }^{87}$ Current members are Chile, Colombia, Peru and Mexico. This is the first regional trade agreement that Chile has concluded after leaving the Andean Community in 1976. Costa Rica is finishing up the process to be incorporated as the Alliance's fifth member, and Panama is also a candidate for joining the bloc.

For PA members, the Alliance implies not only advancing beyond existing trade and market access, but also making commitments that go a step further in the promotion, government procurement, innovation, foreign trade, "single-window", movement of people, and trade facilitation, among other areas. ${ }^{88}$ It can be considered a revival of open regionalism in Latin America. ${ }^{89}$

The Pacific Alliance has already an Additional Protocol to the Framework Agreement, signed on February 10, 2014, where Colombia, Chile, Mexico and Peru commit to liberalize $92 \%$ of their trade, with the remaining $8 \%$ over the coming years. This protocol entered in force since 01 May 2016 and is huge step in regulation of trade and investment between these Southern States, as includes the broadest common disciplines ever negotiated by these countries: in trade in goods, services, market access, non-tariff barriers, rules of origin, trade facilitation, sanitary and phytosanitary measures, technical barriers, government procurement, investment, financial

\footnotetext{
${ }^{86}$ Alberto van Klaveren (n 2).

${ }^{87}$ The Framework Agreement of the Pacific Alliance was signed in Paranal (Chile) with Colombia, Mexico and Peru on June 6, 2012 and entered into force on July 20, 2015. In February 2014, Costa Rica signed a declaration to become a full member of the Alliance including the requirement to have FTAs with each of the member countries. Costa Rica currently has FTAs in force with Chile, Mexico and Peru, and one with Colombia recently entered in force on 01 August 2016. Organization of American States (OAS), Foreign Trade Information System, 'Pacific Alliance' (Trade Policy Developments, 20 June 2014) <http://www.sice.oas.org/TPD/Pacific_Alliance/Pacific_Alliance_e.asp> accessed 19 September 2016.

88 Andrés Rebolledo, 'Entra En Vigencia La Alianza Del Pacífico' <http://www.direcon.gob.cl/2015/07/entra-envigencia-la-alianza-del-pacifico/> accessed 19 September 2016.

${ }^{89}$ Maria Alejandra González-Perez and others, 'La Alianza Del Pacífico: El Regreso Del Regionalismo Abierto a América Latina' (2015) 4 México y la cuenca del pacífico 21.
} 
services, maritime services, electronic commerce, telecommunication, transparency, exceptions, and dispute settlement. The chapter on investment includes investor-state arbitration and provisions on corporate social responsibility and on not lowering health, environmental standards and other regulatory objectives.

The PA Member States maintain a network of FTAs among themselves and with the most developed and dynamic economies of the Asia-Pacific region - like China and Japan - and of the world, including the United States, the EU, and Canada. The PA has considered one novel way of benefiting of that network of treaties: The accumulation of origin. That means that a product from one member country will have a productive transformation in a different country which is also part of the PA, to enable it to comply with the rules of origin and access conditions required in a third country, so that the final product can be entitled to the preferential tariff offered by that country. We will study whether PA accumulation rules affect trade patterns and how. The economic question here is how to ensure spill-over effects and how to limit trade diversion for non-PA members.

However, the Pacific Alliance currently does not include an especial chapter on environmental or labor issues, although the ones previously signed with Colombia and Peru (only in labor issues) are still in force. In recent negotiations, public officials have stressed the need to deepen integration, for which they outlined a roadmap that seeks soon reach agreements on issues of new generation in areas such as infrastructure, Small and medium-sized enterprises (SMEs), health, intellectual property and financial

cooperation, among others.

\section{The Way Ahead}

The failed outcomes of the first wave of Latin American regionalism have been attributed to the absence of political will, manifested as a sustained demand for integration, and the absence of leadership created by the different economic weight of these countries, including "three giants" (Argentina, Brazil and Mexico) with competing economic interests and smaller economies unsure that the benefits of economic integration. ${ }^{90}$

The latest waves of regionalism in Latin America have been associated with liberal and post-liberal economic and political experiments in the region. The open regionalism of the 1990s was replaced during the next decade by post-liberal regionalism. However, the limits — if not the demise — of post-liberal experiments in the most important economies of Latin America place the question of the future of regionalism. Will regionalism hold its sway in Latin America? Will present

${ }^{90}$ Walter Mattli (n 11) 146-147. 
integration schemes continue in the region? Will there be a convergence in diversity between integration projects in Latin America?

From the previous description of a series of unsuccessful initiatives of regional economic integration in Latin America, one can conclude that one of the key impediments to that integration has been the lack of common rules: countries that are part of an integration scheme consistently devise exceptions to it, enact laws and regulations that contradict the common legal framework, stop using those schemes, or simple withdraw from it. Behind all these attitudes lies one assumption: countries are (or should be) independent to establish economic relationship with others. With that frame of mind economic integration in Latin America will never work.

In fact, intra-regional trade accounts for a significant proportion of exports for Europe, Asia and North America. In Europe, trade within the region has accounted for more than $70 \%$ of the region's total merchandise exports on average over the last 20 years. In Asia, over half of its total exports (52\%) were sold within Asia. North America's share of intra-regional trade was slightly lower, with $50 \%$ of its total exports being sold within the region.

For Latin America, trade within the region plays a minor role compared with its overall trade activity, as it also happen for African countries, (18\% per cent of the region's total exports in 2014) and for the Middle East (9\% of the total in 2014). ${ }^{91}$

But, what would happen if countries of the region develop or acquire the same rules? Is there a chance for that integration to work? In the next section we will explore the convergence that some Latin American countries have achieved in several economic disciplines, and if the TPP can serve as a vector to expand this convergence across the region.

\section{Can TPP foster economic integration in Latin America?}

To answer this question one need to compare some relevant provisions of the TPP with ongoing efforts of regional economic integration in Latin America, from the point of view of their goals and objectives, organizational infrastructure, and levels of integration. As we will examine below, most of the existing regional schemes in the region share similar goals with the TPP, but they have different means to implement them, notably on the type of commitments undertaken by the countries and the governance of their agreements.

However, for at least three Latin American members of the TPP (Chile, Mexico and Peru) it is clear that TPP is a de facto consolidation of a type of economic integration that started with

91 World Trade Organization (WTO), 'International Trade Statistics 2015' (2016)
<https://www.wto.org/english/res_e/statis_e/its2015_e/its2015_e.pdf> accessed 1 November 2016. 
NAFTA and then expanded throughout their existing network of PTAs.

As mentioned, the TPP started as an update and enlargement of the P4 Agreement to Australia, Canada, Japan, Malaysia, Mexico, Peru, the United States, and Vietnam, but over time became a more ambitious agreement. For the Chile, Mexico and Peru the TPP implied to move one step beyond the traditional framework of their PTAs, including new disciplines on State enterprises, corruption, regulatory coherence, competition and SMEs, among others. At the same time, TPP updates provisions on intellectual property, telecommunications and e-commerce, and deals with important environmental issues like conservation and trade, biodiversity, climate change, environmental goods and services, corporate social responsibility, and control of illegal fishing. ${ }^{92}$ Although the ratification of TPP is at the time of this writing uncertain, even if it does not happen, it has already had an effect in the consolidation of the model of "deep" preferential trade agreements, as it shown by the example of the Pacific Alliance concluded between the three Latin American members of the TPP and Colombia. Even in the absence of TPP, Chile currently has FTAs with the other 11 countries that have negotiated the agreement. ${ }^{93}$

\section{A. Similar Goals, Different Set-Up}

One can say that Latin American efforts of regional integration have very similar goals to those advanced in TPP, but they envisage very different tools to achieve them.

MERCOSUR's countries declared goal of establishing a common market that provides free movement of goods and services, with a common external tariff, and adopt a common trade policy in relation to third States, is to expand their domestic markets, through integration, as a "vital prerequisite for accelerating their processes of economic development with social justice". ${ }^{94}$ This integration process may include the coordination of macroeconomic and sectoral policies between the States Parties in the areas of foreign trade, agriculture, industry, fiscal and monetary matters, foreign exchange and capital, services, customs, transport and communications and any other areas that may be agreed upon, in order to ensure proper competition between the States Parties. ${ }^{95}$

The main objective for the establishment of CARICOM is to "achieve sustained economic

\footnotetext{
92 Directorate General of International Economic Affairs (DIRECON), 'Acuerdo Transpacífico TPP - Antecedentes Generales' < http://www.direcon.gob.cl/tpp/antecedentes-generales/> accessed 19 September 2016.

93 See: United States Trade Representative, 'TPP Full Text' (December 2015) <https://ustr.gov/trade-agreements/freetrade-agreements/trans-pacific-partnership/tpp-full-text> accessed 19 September 2016. For a detailed account of these negotiations, see: Tania Voon (ed), Trade Liberalisation and International Co-Operation: A Legal Analysis of the Trans-Pacific Partnership Agreement (Edward Elgar Pub 2014); and C. L. Lim, Deborah Kay Elms and Patrick Low (eds), The Trans-Pacific Partnership: A Quest for a Twenty-First Century Trade Agreement (Cambridge University Press 2012).

94 Argentina - Brazil - Paraguay - Uruguay, 'Treaty Establishing A Common Market ('Treaty of Asunción'), 26 March 1991' (1991) 30 International Legal Materials 1041, Preamble, and Art. 1.

95 Treaty of Asunción, Art. 1.
} 
development based on international competitiveness, coordinated economic and foreign policies, functional co-operation and enhanced trade and economic relations with third States". ${ }^{96}$ The original goals of the community put more emphasis on the permanent sovereignty over natural resources, ${ }^{97}$ being very much in line with the so-called "New International Economic Order" (NIEO), articulated in different UN General Assembly Declarations on Permanent Sovereignty over Natural Resources (1962, 1966, 1968, 1970 and 1972) and the Charter of Economic Rights and Duties of States (1974). ${ }^{98}$

CAN stated goals are to "promote the balanced and harmonious development of the Member Countries under equitable conditions, through integration and economic and social cooperation; to accelerate their growth and the rate of creation of employment; and to facilitate their participation in the regional integration process, looking ahead toward the gradual formation of a Latin American Common Market". 99

Although ALBA goals are more of a "post-liberal" nature, there are several points of contact with other efforts of regional integration and TPP as it aims for "economic complementarity and the cooperation between the participating countries and non-competition between countries and productions, in such a way that promotes a productive, efficient and competitive specialization which is compatible with the balanced economic development in every country, with the strategies of fighting against the poverty and with the preservation of the cultural identity of the peoples". ${ }^{100}$ TPP promotes "economic integration to liberalize trade and investment, bring economic growth and social benefits, create new opportunities for workers and businesses, contribute to raising living standards, benefit consumers, reduce poverty and promote sustainable growth". Similarly, among the stated objectives of the Pacific Alliance we find to "build, in a participatory and consensual manner, an area of deep economic integration and to move gradually toward the free

\footnotetext{
96 'Revised Treaty of Chaguaramas Establishing the Caribbean Community Including the Caricom Single Market and Economy, 5 July 2001' (SICE - Foreign Trade Information System, July 2001) Preamble <http://www.sice.oas.org/trade/caricom/caricind.asp> accessed 28 October 2016.

${ }^{97}$ The original text was had a different "accelerated, coordinated and sustained economic development, particularly through the exercise of permanent sovereignty over their natural resources; by the efficient operation of common services and functional cooperation in the social, cultural, educational and technological fields; and by a common front in relation to the external world". 'Treaty Establishing the Caribbean Community. Chaguaramas, 4th July 1973' (SICE - Foreign Trade Information System, 1973) Preamble <http://www.sice.oas.org/Trade/CCME/Chaguaramastreaty_e.pdf> accessed 28 October 2016.

${ }^{98}$ For a more detailed analysis of this movement, see Nico Schrijver, Sovereignty Over Natural Resources: Balancing Rights and Duties (Cambridge University Press 2008).; Andreas F. Lowenfeld, International Economic Law (Oxford University Press 2003) 407-414.; and Antony Anghie, Imperialism, Sovereignty and the Making of International Law (Cambridge University Press 2007) 211-223.

99 Original text was "to promote a balanced and harmonious development of the Member States, to accelerate this development through economic integration, to expedite their participation in the integration processes... designed to secure the progressive improvement of the living standards of the peoples of the Subregion".

${ }^{100}$ ALBA, Principle No. 3, 'Principles of the ALBA' $(A L B A-T C P, 2010)<$ http://alba-tcp.org/en/contenido/principlesalba> accessed 28 October 2016.
} 
circulation of goods, services, capital, and people, and to "Promote the growth, development and competitiveness of the Parties' economies, aiming at achieving greater welfare, overcoming socioeconomic inequalities, and achieving greater social inclusion of their residents". ${ }^{101}$

But to achieve these similar goals, the "traditional" regional schemes of economic integration in Latin America have a different organizational infrastructure than the TPP, that it can be characterized as 'heavy' versus 'light' governance.

For example MERCOSUR, CARICOM, CAN and ALBA have a "heavy load" of institutions, represented in the case of MERCOSUR by the Common Market Council, the Common Market Group, the MERCOSUR Trade Commission, and even a MERCOSUR Parliament (Parlasur). While CARICOM consider a shorter set-up, with a Conference of Heads of Governments, a Community Council and CARICOM Secretariat, the Andean Community has also an expansive infrastructure that mimic the one of the European Union, with a Council of Presidents, an Andean Council of Foreign Affairs, an Andean Community Commission, an Andean Community General Secretariat and the Andean Community Court of Justice.

More recent efforts of Latin American integration do not fare better. ALBA considers not only a Presidential Council, but also a Social Council, a Political Council and a Social Movements Council, together with an Executive Secretariat in charge of the permanent coordination of ALBATCP.

In contrast, TPP offers a model of 'light governance' that only includes the Trans-Pacific Partnership Commission, some sectoral committees and points of contacts for exchange of information. If approved it is still not clear how elaborate the institutional structure will be, and what would be the precise role of private and governmental actors in it. In any case, no superstructure is foreseen for the implementation of the agreement. The Pacific Alliance is the only exception of Latin-American regionalism, as it does not have a formal structure, not even a Secretariat. Only working groups are regularly endowed with the task of advancing with the integration.

Having a 'heavy' governance of economic integration agreements not only supposes budgetary problems but also creates an external decision-making body that is often detached from domestic institutions and politics, a situation that can create problems in the implementation of top-down policies within member countries of the integration scheme. On the other hand, not having basic infrastructure that allows timely exchange of information and steer the functioning of the regional integration can also play against its implementation. This study does not claim that one type of

\footnotetext{
${ }^{101}$ M Angeles Villarreal, 'The Pacific Alliance: A Trade Integration Initiative in Latin America' [2014] Congressional Research Service. United States 1.
} 
governance is better than other, just point out that both TPP and the large majority of Latin American regional integration schemes have a completely different approach in this regard.

\section{B. Different Levels of Integration}

MERCOSUR, CARICOM, CAN and ALBA have different levels of economic integration than TPP. In general, they existing schemes of regional integration in Latin America establish free movement of goods, services and factors of production between countries, but leaving an important autonomy of member states in other disciplines where only "coordination" between members is fostered, like investment, agriculture, industry, fiscal and monetary matters, foreign exchange and capital, transport and communications.

In contrast, TPP is an ambitious trade agreement, including a wide range of disciplines in 30 chapters that would reduce the level of autonomy of contracting parties, but would advance the level of normative convergence. Certain TPP disciplines are not covered neither by MERCOSUR, CARICOM, CAN or ALBA, like e-commerce, regulatory coherence, competitiveness and business facilitation, transparency and corruption, and other disciplines with contested approaches, like investment, intellectual property and data protection, environment and labor, health and security.

The case of investment protection is useful to illustrate the difference of treatment of a discipline. In ALBA countries there is an overall rejection of the current investment system and their search for regional approaches together with UNASUR. ${ }^{102}$ In MERCOSUR there is a stark contrast between Argentina - the Latin American country with more bilateral investment treaties (BITs) in force (55) and the country has faced worldwide the largest number of known investor-state dispute settlement (ISDS) cases, all via investor-state arbitration (59 by the end of December 2015), and Brazil, which has not ratified none of the 14 BITs that signed in the 1990s, is not a contracting party the International Centre for Settlement of Investment Disputes (ICSID) - while Argentina still is, and has recently concluded six Cooperation and Facilitation Investment Agreements (CFIA). ${ }^{103}$ On the top of that the MERCOSUR Protocols of Colonia and Buenos Aires, which were supposed to deal with intra and extra investment protection in MERCOSUR were never ratified. ${ }^{104}$ It is unlikely that TPP will trigger changes in the "traditional" Latin American economic

\footnotetext{
102 Rodrigo Polanco Lazo, 'Beyond ICSID Arbitration - The Centre for Settlement of Investment Disputes of UNASUR' in Andrea K. Bjorklund (ed), Yearbook on International Investment Law and Policy 2014-2015 (Oxford University Press 2016).

${ }^{103}$ Fabio Morosini and Michelle Ratton Sánchez-Badin, 'The Brazilian Agreement on Cooperation and Facilitation of Investments (ACFI): A New Formula for International Investment Agreements?' <https://www.iisd.org/itn/2015/08/04/the-brazilian-agreement-on-cooperation-and-facilitation-of-investments-acfi-anew-formula-for-international-investment-agreements/> accessed 11 January 2016.

${ }^{104}$ Leany Barreiro Lemos and Daniela Campello, 'The Non-Ratification of Bilateral Investment Treaties in Brazil: A Story of Conflict in a Land of Cooperation’ (2015) 22 Review of International Political Economy 1055.
} 
integration, as they have different levels of integration and competing approaches on sensitive issues, unless there is some exception to their common framework, as it will be examined with the example of Uruguay (MERCOSUR member), in another section.

Yet, normative integration could be deeper thanks to TPP in Latin American economic integration schemes that are more alike. That is the case of the Pacific Alliance, where the Additional Protocol to the Framework Agreement has important similarities to the TPP text, as both include chapters on market access, rules of origin, customs administration and trade facilitation, sanitary and phytosanitary measures, technical barriers to trade, public procurement, investment, trade in services, financial services, electronic commerce, and telecommunications, with a very similar content. However, TPP has generally a wider scope and include chapters not considered in the Pacific Alliance framework in disciplines such textiles and apparel, temporary entry for business persons (although this issue has been covered with Memoranda of Understanding between the four member countries), competition policy, competitiveness and business, State-Owned Enterprises, intellectual property, labor and environment, cooperation and capacity building, development, transparency and anti-corruption , and small and medium size enterprises (although the PA include some provisions about it inside the public procurement chapter). Interestingly, only one chapter of the PA Protocol does not have a correlate in TPP: maritime services (chapter 12).

The incorporation in 2015 of a new chapter to the PA's Additional Protocol to the Framework Agreement on regulatory improvement, is a clear example of the influence of TPP in the convergence of economic integration, as it will be explained in the next section.

\section{Regulatory Convergence: the case of the Pacific Alliance}

A more concrete example of the influence of TPP in Latin American regional economic integration is found in the Pacific Alliance's "Regulatory Improvement" chapter. The member countries of the Pacific Alliance (PA) - Chile, Colombia, Mexico and Peru - have concentrated their efforts at regulatory cooperation on a broad swathe of behind the border issues able to deepen intra-regional trade and investment ties and the mobility of talents and ideas. The primary focus of cooperative efforts among PA members has thus been on improving regulatory processes by focusing on transparency and facilitating trade and investment. ${ }^{105}$

On July 3, 2015, the member countries of the PA signed a Protocol Amending the First Additional Protocol to the Framework Agreement of the Pacific Alliance (in force since May $1^{\text {st }}, 2016$ ), which

\footnotetext{
${ }^{105}$ Ministerio de Comercio, Industria y Turismo de Colombia, '100 Preguntas de La Alianza Del Pacífico' (5 February 2016) <http://www.mincit.gov.co/tlc/publicaciones.php?id=7180> accessed 8 February 2016.
} 
includes (in its Annex 4) a new chapter 15a on 'Regulatory Improvement'. ${ }^{106}$ In this chapter, the Parties affirm their shared desire to improve the grouping's regulatory performance through the establishment and systematic implementation of tools such as transparency and public consultation, review and ex ante and ex post measurement of the impact of regulations and the simplification of procedures and services. ${ }^{107}$

The chapter's origin can be traced back to the Fifteenth Meeting of the High Level Group (HLG) of the Pacific Alliance, held in May 2013 in Santiago de Chile, when the HLG agreed to set up a technical group whose mandate was to negotiate a chapter on regulatory improvement from June 2013. As an initial goal, the Parties agreed that this chapter would reflect similar commitments agreed at the time in other processes of trade integration to which PA members were part. Although the idea was for the chapter to be completed by the end of $2014^{108}$ and separated from the Additional Protocol to the PA, the negotiations were extended until mid-2015 and the chapter ended up being a modification of the First Additional Protocol to the PA. According to reports from the PA, the text is based on the 2012 OECD Recommendations on Good Regulatory Practices and the APEC-OECD checklist on regulatory reform. ${ }^{109}$

This new chapter considers internal and external mechanisms in order to 'improve' regulation, foster intensified competition and improve the business environment. ${ }^{110}$ 'Regulatory Improvement' is defined as 'the use of international best regulatory practices in the planning, preparation, adoption, implementation and review of regulatory measures to facilitate the achievement of objectives of national public policy, and the efforts of governments to improve regulatory cooperation in order to achieve these objectives and to promote international trade, investment, economic growth and employment'. ${ }^{111}$

In many ways, the Pacific Alliance's new chapter on regulatory improvement seemed to have influenced the final contours of the TPP text on regulatory coherence. Almost six months before the closing of the TPP text, the Pacific Alliance's chapter considered very similar provisions to the ones found in the TPP. Viewed this way, the Pacific Alliance is arguably at the forefront in developing new disciplines on regulatory convergence within PTAs, with an emphasis on procedural aspects and not in harmonizing or creating common regulations (like in ANZERTA,

\footnotetext{
${ }^{106}$ Alianza del Pacífico, 'First Amending Protocol to the Framework Agreement of the Pacific Alliance' (Documentos, 3 July 2015) <https://alianzapacifico.net/?wpdmdl=4580> accessed 17 February 2016.

${ }^{107}$ Alianza del Pacífico, 'Temas de Trabajo' (Alianza del Pacífico, 8 February 2016) <https://alianzapacifico.net/temasde-trabajo/> accessed 8 February 2016.

108 The Declaration of Presidents of Cartagena de Indias, February 10, 2014, mandated the conclusion of a chapter on regulatory reform within the Alliance for the second half of 2014.

${ }^{109}$ Alianza del Pacífico (n 107).

110 ibid.

${ }^{111}$ First Amending Protocol to the Framework Agreement of the Pacific Alliance, Art. 15 bis2.1
} 
CETA or presumably the TTIP).

For example, the definition of regulatory improvement in the PA (Art. 15bis 2.1) and regulatory coherence in the TPP (Art. 25.2.1) is basically the same, with one telling difference: while the TPP refers to the use of "good regulatory practices", for the PA, regulatory improvement refers to the use of "good international regulatory practices", unconsciously acknowledging that should practices should come from abroad, and not arise endogenously from the PA member countries themselves. Thus, the PA's new chapter focuses on the use of international best regulatory practices, not in the creation of new ones (according to the text, Parties can consider existing measures of member states or of regional forums).

\section{Chile-Uruguay FTA: Breaking Up MERCOSUR?}

Another proxy to test the influence of TPP and TPP-like agreements can be found in the current change in MERCOSUR policy, allowing members to negotiate agreements with third countries. Until recently, the membership in the MERCOSUR, as a customs union, put limits on negotiating trade agreements as an individual country. But an important degree of flexibility has been recently given to Uruguay, which on 4 October 2016 signed a FTA with Chile, and is currently studying the prospect of a trade agreement with China and the United Kingdom. ${ }^{112}$

If we examine the FTA Chile-Uruguay, we can see an important level of convergence towards the TPP Model than to the few PTAs that MERCOSUR has concluded. The structure of the agreement includes several chapters that are included in TPP and the Pacific Alliance, with a very similar content. That is the case of the chapter on trade facilitation (chapter 3, also present in the Pacific Alliance), small and medium enterprises (chapter 4), a detailed chapter on trade in services (chapter 6, also present in the Pacific Alliance), electronic commerce (chapter 8, also present in the Pacific Alliance), competition policy (chapter 9), intellectual property (chapter 10), labor (chapter 11), environment (chapter 12), cooperation (chapter 13), regulatory coherence (chapter 15), transparency and anti-corruption (chapter 16) and a novel chapter on gender and commerce (chapter 14) - not included in TPP which only has a provision on women and economic growth (Article 23.4). This is the first treaty signed by Chile that addresses this issue; having both countries will encourage the presence of women in international trade. In this chapter, among other guidelines, the parties reaffirm their commitment to effectively implement its legislation, policies and good practices on equity and gender equality, recognizing international trade as an engine of

\footnotetext{
${ }^{112}$ Leonardo Luzzi, 'Gobierno Celebra Gesto de Brasil Para Admitir Acuerdos Fuera Del Mercosur' El Observador (Montevideo, Uruguay, 7 May 2015) <http://www.elobservador.com.uy/gobierno-celebra-gesto-brasil-admitiracuerdos-fuera-del-mercosur-n304541> accessed 26 September 2016.
} 
development and which recognize the importance of incorporating the gender perspective in promoting inclusive economic growth. ${ }^{113}$

It is important to note that both countries have previously renegotiated a bilateral investment treaty in 2010, that will subsist after the entry into force of the FTA (and that is the reason why there is no investment chapter in is text), and which content is very similar to the investment chapter that Chile concluded in the FTA with the United States (and later to the investment chapter of the PA's Additional Protocol to the Framework Agreement).

Although Chile has stressed that the FTA with Uruguay "reflects the areas already agreed in the agreement that Chile has since 20 years with MERCOSUR", ${ }^{114}$ the difference not only in the depth of regulation of the disciplines but also with the addition of the "new issues" (such electronic commerce, trade in services, labor, environment, gender, cooperation), but a question mark on the future of this scheme of regional integration, especially if Uruguay persist in its intention of concluding similar agreements with other third countries.

On the other hand, it will be important to see what other MERCOSUR countries do. Some years before the "flexibility" that allowed Uruguay to sign the FTA with Chile, Paraguay explicitly explored the possibility of a deeper economic integration with the alliance. ${ }^{115}$

If eventually Paraguay becomes a PA member, it will have to find a way to make it compatible with the common external tariff (CET) that is committed within MERCOSUR, considering that one declared goal of MERCOSUR is to reduce CET perforations by $2019 .{ }^{116}$ A proposal made by Chile about "convergence in diversity" should be analyzed as a way to deal with the interplay between Alliance Pacific and MERCOSUR, considering that it aims at a redesign focused on the production chain and the availability of physical connectivity and trade facilitation in the main corridors of regional productivity. ${ }^{117}$

\section{Conclusion}

We can conclude that TPP has served as fostered convergence for a group of countries in the Latin

\footnotetext{
${ }^{113}$ Directorate General of International Economic Affairs (DIRECON), 'Chile Y Uruguay Suscribieron Hoy Acuerdo Comercial' (4 October 2016) <https://www.direcon.gob.cl/2016/10/chile-y-uruguay-suscribieron-hoy-acuerdocomercial/> accessed 2 November 2016.

114 ibid.

115 Stella Guillén, 'Paraguay Frente Al Mercosur Y La Alianza Del Pacífico' (CADEP, March 2013) <http://www.cadep.org.py/uploads/2013/03/Articulo-SG-full-color.pdf> accessed 2 November 2016.

${ }^{116}$ Fundación INAI, 'La Importancia Del Arancel Externo Común Del Mercosur a 20 Años de La Conformación Del Bloque' (2011) C Revista de la Bolsa de Comercio de Rosario 28.

${ }^{117}$ Francisco N. González Díaz, 'The Pacific Alliance and Global Value Chains', Negocios ProMéxico Mayo: The Pacific Alliance and the Latin American Integration (ProMéxico 2014) 26.
} 
American region that already had an important participation on preferential trade agreements and investment treaties. NAFTA/TPP model is definitely the one followed by the Latin American members of the TPP: Chile, Mexico and Peru and some other countries of the region that embraced open regionalism (notably, Colombia, Costa Rica and Panama). In many cases, TPP will broaden or improve upon commitments in existing agreements. For example, the commitments Mexico, Chile, and Peru have made in TPP's Labor and Environment chapters broaden and improve those previously undertaken under NAFTA and prior FTAs. But in some cases having parallel agreements between the same countries on the same disciplines could create problems: for example in the presence of investment chapters in TPP, NAFTA and other Latin American Bilateral FTAs, if we assume that TPP investment chapter has a more balanced approach in the protection of foreign investors while respecting the policy space of States to regulate, why should investors should choose TPP protection over NAFTA protection if that treaty would continue to be in force even if TPP is ratified? ${ }^{118}$ If TPP will serve as future model for economic integration, countries should handle more clearly the problems derived from the coexistence of parallel agreements that are not entangled as a 'spaghetti bowl', but as a 'lasagna dish' with different layers of protection that overlap with each other.

TPP is also likely to influence other countries of the region that have not a large experience on PTAs except under a regional approach (Uruguay, Paraguay) in as much as they have the flexibility to do it. But TPP won't be the next model to all Latin American Preferential Trade and Investment Agreements, as it is unlikely that the TPP will influence Latin America countries that are openly against the system of PTAs (ALBA countries) or that have kept themselves outside of the system of PTAs and of IIAs (like Brazil).

The coexistence of different schemes of economic integration presents a challenge for Latin America, and their countries should define the different links between existing processes of integration in the same geographical area, not only a sub-regional level (MERCOSUR, CAN, ALBA, Pacific Alliance, etc...), but also with in the overall Latin America and the Caribbean (UNASUR, LAIA). Although some have been smoothing rough edges, (particularly MERCOSUR with UNASUR and the CAN), where there has been an effort to have complementarity rather than competition, there are still many issues to save. Flexibility has been used to deal with this issue, but how much flexible an agreement can be without losing consistency?

\footnotetext{
${ }^{118}$ Few TPP parties took the decision of terminating existing agreements if the TPP is finally ratified. This is the case of Australia that agreed to terminate its BITs with Mexico (2005), Peru (1995) and Vietnam (1991), on a side letter to the TPP. Australian Government, TPP TEXT AND ASSOCIATED DOCUMENTS DEPARTMENT OF FOREIGN AFFAIRS AND TRADE (2016), http://dfat.gov.au/trade/agreements/tpp/official-documents/Pages/official-documents.aspx (last visited Oct 5, 2016).
} 
Only time will tell if TPP will help the process of convergence or further even more fragmentation between the two competing models, different ideologies and integration projects in the region: the 'Atlantic" ${ }^{\prime 19}$ one with countries overall more protectionist and focused in integration beyond the economic aspects (including political and social issues) and an overall rejection of investment treaties, and the 'Pacific' model, with countries aiming more open and liberalized markets, with reduced political and social components of economic integration, and overall acceptance of the NAFTA model and of international investment agreements.

${ }^{119}$ The geographic exception to this model would be Ecuador. 